\title{
Selection of prime mover for combined cooling, heating, and power systems based on energy savings, life cycle analysis and environmental consideration
}

\author{
${ }_{4}$ Q1 Kibria Roman*, Jedediah Alvey \\ 5 Q2 Department of Mechanical Science and Engineering, University of Illinois at Urbana-Champaign, United States
}

\section{$24 \quad$ A R T I C L E I N F O}

\section{Article history:}

Received 15 June 2015

Received in revised form 7 October 2015

Accepted 23 October 2015

Available online $\mathrm{xxx}$

\section{Keywords:}

CCHP systems

Operation strategies

Energy

ICE

Micro-turbine

Fuel cell

Emission reduction

Economic analysis

\begin{abstract}
A B S T R A C T
Selection of prime mover type was investigated for use in combined cooling, heat and power systems. Selection was determined from comparison of performance criteria for economic, energy and emissions savings. Simulations were run for three different types of prime movers in one climate zone and compared to a reference case with a typical separate heating and power system in the same climate zone. A hybrid load following method was implemented, with a suggested improvement. Performance parameters were compared and results indicated emissions and energy savings for all three prime movers. The prime mover types were reciprocating internal combustion engine (ICE), micro-turbine and phosphoric acid fuel cell. The climate zone was chosen to be a cold, humid climate represented by Chicago, IL. Economic savings were seen for both the ICE and micro-turbines. Emissions savings for carbon, nitrogenoxides and methane, for all three types, were greater than $9 \%, 12 \%$, and $13 \%$, respectively. Primary energy consumption savings for all three were greater than $8 \%$.
\end{abstract}

(c) 2015 Published by Elsevier B.V.

\section{Introduction}

Cogeneration or combined heat and power (CHP) systems are implemented throughout the United States. They allow for the utilization of waste heat from the on-site generation of electricity. The waste heat is used to help meet the thermal demands of the building. Similarly with the use of absorption chillers, the waste heat can also be used to help meet the cooling demands of a building. This is known as combined cooling, heating and power (CCHP) or trigeneration. The Department of Energy is currently working toward a goal of increasing CHP capacity by 40 GW by the year 2020 [1].

Combined systems must run on some sort of load following scheme. For systems with a single prime mover schemes that follow the electric load or that follow the thermal load is often used $[2,3]$. Smith and Mago [4] evaluated the performance of a hybrid scheme that followed either the electric load or the thermal load in a given time period. The results show that efficiency is improved by using the hybrid load following scheme, leading to efficiencies around $80 \%$. It is also possible to use base loading [5] where the prime mover is run at a constant base loading, or to use multiple prime

\footnotetext{
* Corresponding author.

E-mail address: mgkhan2@illinois.edu (K. Roman).
}

movers with one operating at a base load with the other operates under one of the load following schemes [6].

Such sytems are largely found in industrial settings [7], but can also be implemented in a variety other building types and sizes. Studies from Mago and Luck [8] and Kavvadias et al. [9] both evaluated the benefits of combined systems in hospital buildings. Knizley et al. [10] used a restraint building to illustrate the benefits of using dual prime movers in a combined system. Smith and Mago [4] demonstrate the use of different load following strategies for a large hotel. Mago et al. [11] evaluated the use of micro-CCHP $(<30 \mathrm{~kW})$ and determined that the use of hybrid load following had the bestsimulated performance. Because of physical limitations, according to Ebrahimi and Keshavarz [12], hybrid load following on such a small prime mover may not be feasible, and they propose a sizing and load following strategy to make the use of CCHP in a multi-unit residential building feasible. Many of these studies focus on the optimization of combined systems regarding size of prime mover and load following strategies [13-15]. The current study seeks to present a strategy for selecting the type of prime mover to be used, e.g. combustion engines, turbines, etc.

The operation of a CCHP system, and thus the choice of prime mover, depends on several parameters. These include the climate zone, building thermal and power demands, costs of fuel compared to electricity, the availability to sell excess electricity back to the 


\begin{tabular}{|c|c|}
\hline \multicolumn{2}{|c|}{ Nomenclature } \\
\hline AC & Absorption chiller \\
\hline $\mathrm{AOC}$ & Annual operating cost \\
\hline AS & Annual savings \\
\hline CC & Compression chiller \\
\hline CCHP & Combined cooling, heating, and power \\
\hline $\mathrm{CDE}$ & Carbon dioxide emissions \\
\hline COP & Coefficient of performance \\
\hline $\mathrm{Em}$ & Emission \\
\hline EUAC & Equivalent uniform annual saving \\
\hline $\mathrm{F}$ & Fuel \\
\hline $\mathrm{HE}$ & Heat exchanger \\
\hline $\mathrm{HC}$ & Heating coil \\
\hline IC & Initial cost \\
\hline ICE & Internal Combustion Engine \\
\hline IRR & Internal rate of return \\
\hline MARR & Minimum attractive rate of return \\
\hline ME & Methane emission \\
\hline NXE & Nitrogen oxide $\left(\mathrm{NO}_{x}\right)$ emission \\
\hline PM & Prime mover \\
\hline SEC & Site energy consumption \\
\hline SPP & Simple payback period \\
\hline SS & Spark spread \\
\hline $\mathrm{COP}_{A C}$ & Coefficient of performance of absorption chiller \\
\hline COP & Coefficient of performance of compression chiller \\
\hline$C_{N G, \text { elec }}$ & Cost of natural gas/electric per kWh \\
\hline$C_{o m}$ & $\begin{array}{l}\text { Cost of operation and maintenance except fuel per } \\
\mathrm{kWh}\end{array}$ \\
\hline$E_{B}$ & $\begin{array}{l}\text { Total electricity supplied from grid and the prime } \\
\text { mover }\end{array}$ \\
\hline$E_{C C}$ & Electricity supplied to compression chiller \\
\hline$E_{E D}$ & $\begin{array}{l}\text { Building electricity demand except the chiller elec- } \\
\text { tricity requirement }\end{array}$ \\
\hline$E_{\text {Grid }}$ & Electricity purchased from grid \\
\hline$E_{P M}$ & Electricity generated by the prime mover \\
\hline$E_{P M_{\max }}$ & Rated capacity of the prime mover \\
\hline & $\begin{array}{l}\text { Electricity supplied to the building except compres- } \\
\text { sion chiller }\end{array}$ \\
\hline$E m_{S}$ & Emission savings \\
\hline$F_{\text {boiler }}$ & Fuel consumed by the boiler \\
\hline$F_{m}$ & $\begin{array}{l}\text { Fuel required for both the boiler and the prime } \\
\text { mover }\end{array}$ \\
\hline$F_{P M}$ & Fuel consumed by the prime mover \\
\hline$L_{P M}$ & Lifetime of the prime mover \\
\hline$P_{P M}$ & Prime mover rated capacity \\
\hline$Q_{A C}$ & $\begin{array}{l}\text { Cooling energy supplied to the building by absorp- } \\
\text { tion chiller }\end{array}$ \\
\hline$Q_{\text {Boiler }}$ & Heating energy supplied by the boiler \\
\hline$Q_{\text {bldD }}$ & Design thermal demand for the building \\
\hline$Q_{c c}$ & $\begin{array}{l}\text { Cooling energy supplied to the building by compres- } \\
\text { sion chiller }\end{array}$ \\
\hline$Q_{C D}$ & Cooling load demand \\
\hline$Q_{H D}$ & Heating load demand \\
\hline$Q_{H E}$ & Heat recovered from the heat exchanger \\
\hline$Q_{H E_{\max }}$ & $\begin{array}{l}\text { Maximum possible heat extraction from the heat } \\
\text { exchanger }\end{array}$ \\
\hline$Q_{H E_{o p t}}$ & $\begin{array}{l}\text { Optimum heat extraction from the heat exchanger } \\
\text { to meet the prime mover electric load }\end{array}$ \\
\hline$Q_{P M}$ & Waste heat energy available from prime mover \\
\hline$\eta_{H E}$ & Heat exchanger efficiency \\
\hline$\eta_{\text {Boiler }}$ & Boiler efficiency \\
\hline
\end{tabular}

$\begin{array}{ll}\eta_{H C} & \text { Heating coil efficiency } \\ \psi & \begin{array}{l}\text { Factor of heat losses from prime mover to heat } \\ \text { exchanger }\end{array} \\ \xi & \text { Interest rate }\end{array}$

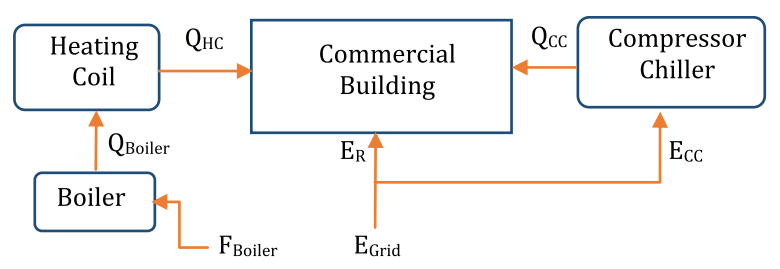

Fig. 1. Schematic of reference system.

grid excess electricity, and the capability for electric or thermal storage $[4,5,11,12,16-22]$. Sanaye et al. [20] studied the selection between diesel engine, gas engine and gas turbine prime movers with electric load following, with and without the ability to sell back electricity, but did not evaluate the use of fuel cell prime movers. Yang et al. [23] investigated how the use of fuel cell generators, used in combination with ground source heat pumps, could produce primary energy consumption savings, while potentially also yielding operational savings. An in-depth analysis of HVAC systems is not included in this study, as several studies have addressed this [24-27].

The current study investigates the use of CCHP in a cold, humid climate (Chicago, IL) for a medium sized office building with an operational strategy and does not consider power storage or the ability to sell back electricity. This study seeks to outline the process and parameters for choosing which type of prime mover (reciprocating engines, gas turbines or fuel cell prime movers) to use for a single prime mover setup run with a hybrid load following scheme. Additionally an improvement on the hybrid load following method is presented, where the non-constant relationship between efficiency and partial loading of the prime mover is considered. Electricity sellback was not considered in this study because the hybrid load following method used does not result in excess electricity generation. Thermal storage was not included in this study because it is expected that the use of thermal storage would generally improve the cost, energy consumption and emissions for all types of prime movers [5].

Results from simulations for different prime movers are compared to a reference separate cooling, heating and power system. They are evaluated in terms of economic, energy conservation and emissions mitigation. Parameters indicating cost savings are the simple payback period (SPP), annual savings (AS), internal rate of return (IRR) and equivalent uniform annual savings (EUAS). The energy savings parameter used is primary energy consumption (PEC). As indicated by the results from Fumo et al. [28], site energy consumption (SEC) will always increase when CCHP is used, while PEC can still be decreased, and thus PEC is a better indicator of system feasibility. Finally, emissions savings are determined for carbon dioxide $\left(E m_{s, C D}\right)$, nitrogen oxides $\left(E m_{s, N X}\right)$, and methane $\left(E m_{s, M}\right)$.

\section{Methodology}

\subsection{CCHP system model}

A typical separate cooling, heating and energy system is illustrated in Fig. 1 for comparison with the proposed CCHP system. A schematic of the proposed system is illustrated in Fig. 2. The associated equations for the system are developed as follows. 


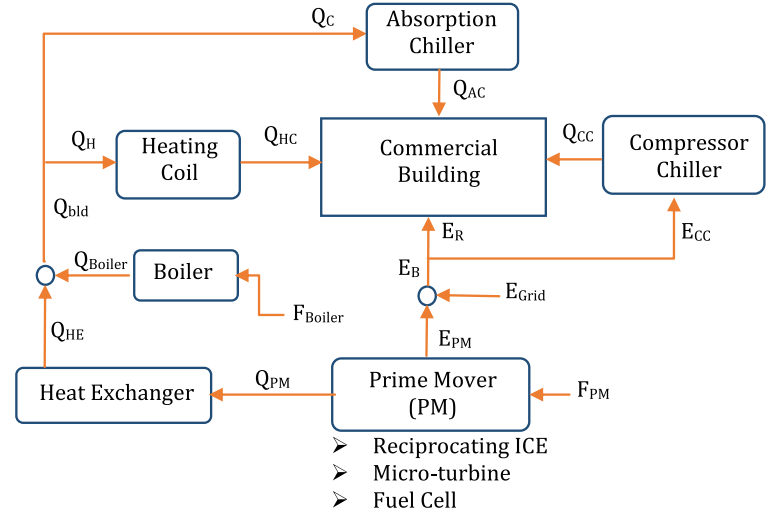

Fig. 2. Schematic of proposed CCHP system.

The electricity generated from the prime mover (PM), $E_{P M}$, can be expressed as $[4-6,29,30]$,

$E_{P M}=F_{P M}-Q_{P M}$,

where $F_{P M}$ is the fuel consumed by the PM and $Q_{P M}$ is waste heat generated from the prime mover. The efficiency of the PM is defined such that:

$E_{P M}=\eta_{P M} F_{P M}$.

The total electricity supplied to the building $E_{B}$ is given by

$E_{B}=E_{P M}+E_{\text {Grid }}$,

where $E_{\text {Grid }}$ is the electricity supplied from the grid. The buildings electric supply can also be represented in terms of the electricity supplied to the compression chiller, $E_{C C}$, and all other electricity supplied to the building:

$E_{B}=E_{R}+E_{C C}$

The necessary electricity supplied to the compression chiller, in terms of the cooling energy supplied to the building by the compression chiller, $Q_{c c}$, is

$E_{C C}=\frac{Q_{C C}}{{ }^{C O P} P_{C C}}$

Here, $\mathrm{COP}_{\mathrm{CC}}$ is the coefficient of performance of the compression chiller.

The waste heat recovered by the heat exchanger is given by [4]

$Q_{H E}=\psi \eta_{H E} Q_{P M}$,

where $\psi$ is a factor that accounts for losses from the prime mover to the heat exchanger and $\eta_{\mathrm{HE}}$ is the efficiency of the heat exchanger. The amount of fuel energy required for the PM can be expressed as a function of the desired electricity output from the PM. From manufacturer data [31] for efficiency vs. partial load of the PM, a curve fit can be applied to represent such a function; the fuel consumption is determined from Eq. (2) with the efficiency and the electricity output (as determined by the partial load). The study by Smith and Mago [4] uses a linear curve fit to manufacturer data to create such a relationship between the fuel required and electricity generated by the prime mover. However, the non-constant nature of efficiency vs. partial load of most prime movers leads to a nonlinear relationship between fuel required and electricity generated. The current study proposes that a quadratic curve fit to the manufacturer's data be used, to provide a better relationship between required fuel and electricity generated:

$F_{P M}=a E_{P M}^{2}+b E_{P M}+c$.
The constants $a, b$ and $c$ are determined for the particular PM in use. By combining (7), (6) and (1), the heat recovered by the heat exchanger can be rewritten as

$Q_{H E}=\alpha E_{P M}^{2}+\beta E_{P M}+\gamma$,

where $\alpha=\mathrm{a} \psi \eta_{\mathrm{HE}}, \beta=(b-1) \psi \eta_{\mathrm{HE}}$ and $\gamma=c \psi \eta_{\mathrm{HE}}$ can again be determined for the particular PM in use.

The building thermal load is the sum of the heat recovered by the heat exchanger and the heat from the boiler [4], which is equal to the sum of the heat supplies to the heating coil and absorption chiller:

$Q_{\text {bld }}=Q_{H E}+Q_{\text {Boiler }}=Q_{C}+Q_{H}$

The building design thermal demand, $Q_{b l d D}$, is assumed to depend only on the heating and cooling load demands, which can be defined as

$Q_{b l d \_D}=\frac{Q_{H D}}{\eta_{H C}}+\frac{Q_{C D}}{C O P_{A C}}$,

where $Q_{H D}$ and $Q_{C D}$ are the heating load demand and cooling load demand, respectively. The heating coil efficiency, $\eta_{H C}$, and the absorption chiller coefficient of performance, $C O P_{A C}$, are defined below:

$Q_{A C}=C O P_{A C} Q_{C}$

$Q_{H C}=\eta_{H C} Q_{H}$

The boiler efficiency, $\eta_{H C}$, is defined as follows:

$Q_{\text {Boiler }}=\eta_{\text {Boiler }} F_{\text {Boiler }}$

The calculation of performance parameters ( $E_{\text {grid }}, E_{P M}, F_{m}, Q_{A C}$, $Q_{\text {boiler }}, Q_{C C}$, and $Q_{H E}$ ) depends on the nature of the thermal and electric load demands. Different zones are defined in Fig. 3 that represent four different combinations of the two loads, in relation to the optimum demands. The solid line between zones 2 and 3 represents the optimum thermal load for a given electric load, which can be calculated by using Eq. (8). This is where the building design thermal load is precisely matched with the recovered waste heat from PM for a given electric demand. Scenarios where the demand combination does not fall on this line will require grid supplied electricity or supplemental boiler heating/compression chiller cooling. During each iteration of a simulation, the zone is determined from the current thermal and electric loads. Within each zone, multiple scenarios can occur. The specifics for each zone and its scenarios, and the implications for calculating the relevant quantities, are described in detail in the following sections.

\subsubsection{Zone 1}

For zone 1 the required thermal load is below the minimum recoverable heat from the PM, $Q_{b l d} D<Q_{H E_{\min }}$. The PM will not operate and the electricity and fuel will be imported from grid. Based on building thermal demands three operating conditions can occur.

2.1.1.1. Case 1A. For this case $Q_{\mathrm{HD}} \& E_{\mathrm{ED}}>0$ and $Q_{C D}=0$. The metered fuel purchased $F_{m}$ is used to operate the boiler and building electric demand is completely supplied from the grid, as if it were a separate heat and power system:

$E_{\text {grid }}=E_{\mathrm{ED}}$

$F_{m}=F_{\text {boiler }}=\frac{Q_{H D}}{\eta_{H C} \eta_{\text {Boiler }}}$

$Q_{c c}=0$ 


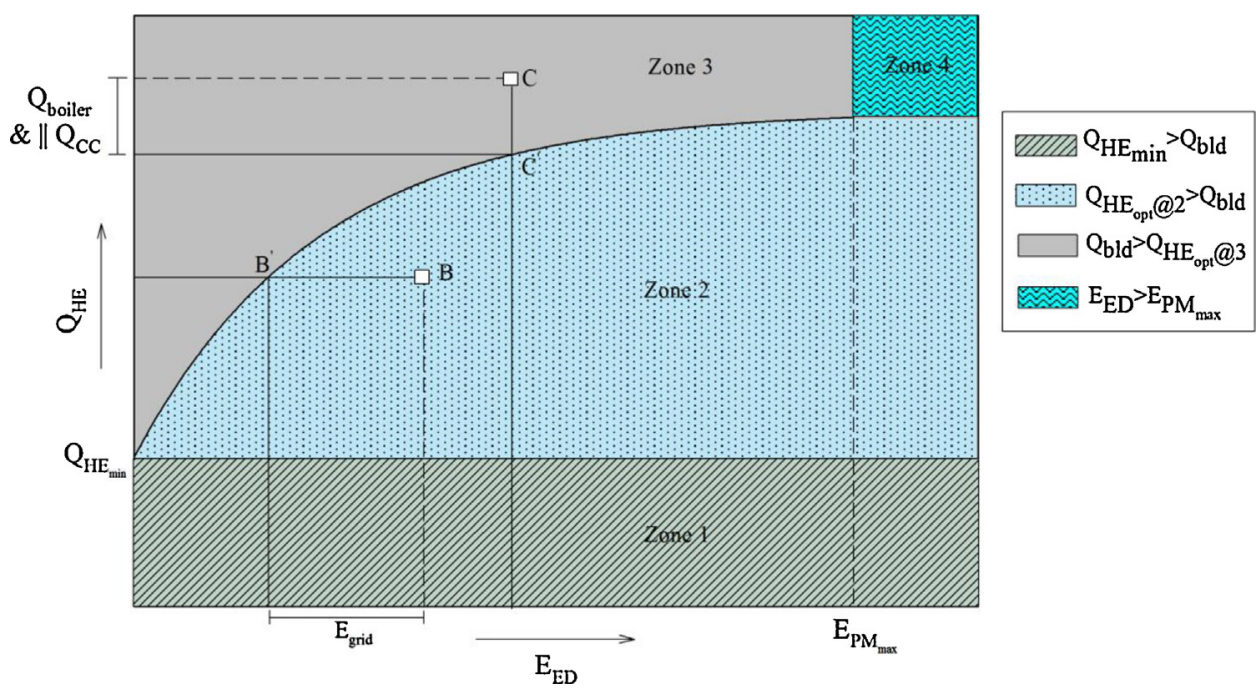

Fig. 3. Hybrid load following strategies for different operating conditions.

2.1.1.2. Case 1B. For this case $Q_{C D} \& E_{\mathrm{ED}}>0$ and $Q_{H D}=0$. The metered fuel $F_{m}$ is zero since heating demand is absent and the compression chiller supplies building cooling demand. Electric demand includes the operation of the compression chiller and is completely supplied from the grid:

$E_{\text {grid }}=E_{\mathrm{ED}}+\frac{Q_{\mathrm{CD}}}{\mathrm{COP}_{\mathrm{CC}}}$

$F_{m}=0$

$Q_{C C}=Q_{C D}$

2.1.1.3. Case 1C. For this case $Q_{C D} \& E_{\mathrm{ED}}>0$ and $Q_{H D}>0$. The metered fuel purchased, $F_{m}$ is used to operate the boiler. Building electric demand and cooling demand is supplied from the grid:

$E_{\text {grid }}=E_{\mathrm{ED}}+\frac{Q_{C D}}{C O P_{C C}}$

$F_{m}=F_{\text {boiler }}=\frac{Q_{H D}}{\eta_{H C} \eta_{\text {Boiler }}}$

$Q_{C C}=Q_{C D}$

\subsubsection{Zone 2} the PM exhaust heat energy. As a result, there is no need for additional cooling from the compressor chiller:

$Q_{c c}=0$

A sample point B in Fig. 3 is used to illustrate the supply of building thermal and electric loads in this zone. Building thermal demand, $Q_{\text {bld } D}$, is computed from (10). The optimum heat extracted from heat exchanger, $Q_{H E_{o p t} @ 2}$, for the building electric demand, $E_{\mathrm{ED}}$, can be found using (25):

$E_{B}=E_{\mathrm{ED}}$

$Q_{\mathrm{HE}_{o p t} @ 2}=\alpha E_{\mathrm{ED}}^{2}+\beta E_{\mathrm{ED}}+\gamma$

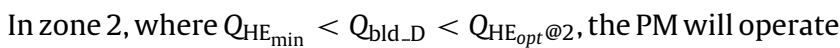
at $\mathrm{B}^{\prime}$ (see Fig. 3). At the PM operating point, heat recovered by the heat exchanger is equal to the building thermal demand, as shown in (26):

$Q_{H E @ 2^{\prime}}=Q_{b l d \_D}$

Electricity generated by the prime mover at this operating point, $E_{P M @ 2^{\prime}}$, is extracted from (8), resulting in (27). The grid-supplied
For zone 2 the building thermal load can be fully extracted from demand and the result from (27):

$E_{\mathrm{PM} 2^{\prime}}=\frac{1}{2 \alpha} \sqrt{\beta^{2}-4 \alpha\left(\gamma-Q_{\mathrm{HE} @ 2^{\prime}}\right)}-\frac{\beta}{2 \alpha}$

$E_{\text {grid }}=E_{\mathrm{ED}}-E_{\mathrm{PM} 2^{\prime}}$

\subsubsection{Zone 3}

For zone 3, when $Q_{\mathrm{HE}_{\text {opt }} @ 3}<Q_{\text {bld_D }} \& E_{\mathrm{ED}} \leq E_{\mathrm{PM}_{\max }}$, the electric demand without the compression chiller, $E_{R}$, can be supplied by the PM. A sample point C in Fig. 3 is used to illustrate the supply of building thermal and electric loads in this zone. Depending on the building thermal demands, five operating conditions can occur. In each of the zone 3 cases, the PM would operate at $C^{\prime}$, where the electric demand is supplied by the PM and the heat recovered by the heat exchanger is determined from (8):

$E_{P M}=E_{\mathrm{ED}}$

$Q_{H E}=\alpha E_{\mathrm{ED}}^{2}+\beta E_{\mathrm{ED}}+\gamma$

2.1.3.1. Case $3 A$. For this case $Q_{H D} \& E_{\mathrm{ED}}>0$ and $Q_{C D}=0$. Since there is no cooling requirement, no supplemental electric supply is needed:

$Q_{c C}=0$

$E_{\text {grid }}=0$

The boiler makes up the difference between building heat demand and recovered heat and the total fuel required is determined as

$F_{m}=F_{P M}+F_{\text {boiler }}=F_{P M}+\left(\frac{Q_{H D}}{\eta_{H C}}-Q_{H E}\right) \frac{1}{\eta_{\text {Boiler }}}$. does not need to supply any additional heat, so the total fuel required is the fuel supplied to the PM:

$F_{m}=F_{P M}$

The maximum cooling power supplied by the recovered heat can be determined as

$Q_{A C}=Q_{H E} C O P_{A C}$. electricity is then the difference between the building electric

2.1.3.2. Case $3 B$. For this case $Q_{C D} \& E_{\mathrm{ED}}>0$ and $Q_{H D}=0$. The boiler power systems based on energy savings, life cycle analysis and environmental consideration, Energy Buildings (2015), http://dx.doi.org/10.1016/j.enbuild.2015.10.047 
${ }_{271} \quad E_{\text {grid }}=\frac{Q_{C C}}{C O P_{C C}}$

$Q_{C C}=Q_{C D}$

$E_{\text {grid }}=\frac{Q_{C C}}{\operatorname{COP}_{C C}}$

$E_{\text {grid }}=\frac{Q_{C C}}{C O P_{C C}}$.

$Q_{c c}=0$

$E_{\text {grid }}=0$

\subsubsection{Zone 4}

and

$Q_{H E}=Q_{H E \max }$.
Supplemental cooling is provided by the compression chiller, which requires additional electricity supplied from the grid:

$Q_{C C}=Q_{C D}-Q_{A C}$

2.1.3.3. Case 3C. For this case $Q_{C D} \& E_{E D}>0$ and $Q_{H D} \geq Q_{H E}$. Again, the boiler makes up the difference between building heat demand and heat recovered, and the total required fuel is

$F_{m}=F_{P M}+F_{\text {boiler }}=F_{P M}+\left(\frac{Q_{H D}}{\eta_{H C}}-Q_{H E}\right) \frac{1}{\eta_{\text {Boiler }}}$.

In this case, cooling is also required. It is supplied completely by the compression chiller, requiring grid electricity:

2.1.3.4. Case 3D. For this case $Q_{H D} \& E_{E D}>0$ and $\frac{Q_{C D}}{\operatorname{COP}_{A C}} \geq Q_{H E}$. This case is similar to $3 \mathrm{C}$, except that here the boiler covers the entire heating demand while all of the recovered heat is used in the absorption chiller to provide cooling. The total required fuel is determined from

$F_{m}=F_{P M}+F_{\text {boiler }}=F_{P M}+\left(\frac{Q_{H D}}{\eta_{H C}}\right) \frac{1}{\eta_{\text {Boiler }}}$.

The available cooling power supplied from recovered heat is

$Q_{A C}=Q_{H E} C O P_{A C}$

and the remaining cooling needed is

$Q_{C C}=Q_{C D}-Q_{A C}$,

which requires an electric supply from the grid according to

2.1.3.5. Case $3 E$. For this case $\frac{Q_{C D}}{\operatorname{COP} P_{A C}}<Q_{H E}$ and $\frac{Q_{H D}}{\eta_{H C}}<Q_{H E}$. The recovered heat will be used to supply the needed cooling with the absorption chiller, meaning no extra cooling with the compression chiller is needed:

The remaining recovered heat supplies part of the building heating demand. The boiler provides the necessary additional heating. The needed supply of heat from the boiler is the difference between the building thermal demand and the available recovered heat, and the metered fuel consumption is

$F_{m}=F_{P M}+F_{b o i l e r}=F_{P M}+\left(Q_{b l d D}-Q_{H E}\right) \frac{1}{\eta_{\text {Boiler }}}$.

For zone 4, when $Q_{\text {bld_D }}>Q_{\mathrm{HE}_{\max }} \& E_{\mathrm{ED}}>E_{\mathrm{PM}_{\max }}$, deficiencies in both heating and cooling will occur, with respect to the supply of the PM. Depending on the building thermal demands, five operating conditions can occur. For each of the cases in zone 4, the PM is operating at its nominal load so that

$E_{\mathrm{PM}}=E_{\mathrm{PM}_{\max }}$,
2.1.4.1. Case 4A. For this case $Q_{H D}>0$ and $Q_{C D}=0$. In this case, the grid-supplied electricity makes up the difference for electrical demand, while the boiler makes up the difference for the heating demand:

$E_{\text {grid }}=E_{\mathrm{ED}}-E_{\mathrm{PM}_{\max }}$

$F_{m}=F_{P M}+F_{\text {boiler }}=F_{P M}+\left(\frac{Q_{H D}}{\eta_{H C}}-Q_{H_{\text {max }}}\right) \frac{1}{\eta_{\text {Boiler }}}$

$Q_{c C}=0$

2.1.4.2. Case $4 B$. For this case $Q_{C D}>0$ and $Q_{H D}=0$. Here the gridsupplied electricity makes up the difference for electrical demand and provides power for the compressor chiller:

$E_{\text {grid }}=\frac{Q_{C C}}{{ }_{C O P C}}+E_{\mathrm{ED}}-E_{\mathrm{PM}_{\max }}$

No additional heating is required, so the fuel required is only what the PM requires:

$F_{m}=F_{P M}$

The absorption chiller provides some of the cooling, with the remaining cooling load provided by the compression chiller:

$Q_{A C}=Q_{H E} C O P_{A C}$

$Q_{C C}=Q_{C D}-Q_{A C}$

2.1.4.3. Case 4C. For this case $Q_{C D}>0$ and $\frac{Q_{H D}}{\eta_{H C}}>Q_{H E}$ max . Since the heating demand is larger than available from the recovered heat, the boiler will supply additional heat. The required fuel will be

$F_{m}=F_{P M}+F_{\text {boiler }}=F_{P M}+\left(\frac{Q_{H D}}{\eta_{H C}}-Q_{H E \max }\right) \frac{1}{\eta_{\text {Boiler }}}$.

Additionally, the compression chiller will satisfy the cooling demand,

$Q_{C C}=Q_{C D}$,

and the grid-supplied electricity will be

$E_{\text {grid }}=\frac{Q_{C C}}{C_{C O}}+E_{\mathrm{ED}}-E_{\mathrm{PM}_{\max }}$.

2.1.4.4. Case $4 D$. For this case $Q_{H D}>0$ and $\frac{Q_{C D}}{C O P}>Q_{H E \max }$. Here the boiler supplies the needed heat, while the absorption chiller uses the recovered heat to satisfy part of the cooling demand. The compression chiller covers the remaining part of the cooling demand. Thus the grid supplies the needed electricity beyond the maximum that the PM can provide, including the use of the compression chiller:

$E_{\text {grid }}=\frac{Q_{C C}}{C O P_{C C}}+E_{\mathrm{ED}}-E_{P_{\max }}$

The fuel required is

$F_{m}=F_{P M}+F_{\text {boiler }}=F_{P M}+\frac{Q_{H D}}{\eta_{H C}} \frac{1}{\eta_{\text {Boiler }}}$.

The available cooling from the absorption chiller is

$Q_{A C}=Q_{H E} C O P_{A C}$,

and the cooling needed from the compression chiller is

$Q_{C C}=Q_{C D}-Q_{A C}$. 
2.1.4.5. Case $4 E$. For this case $\frac{Q_{H D}}{\eta_{H C}}<Q_{H E_{\max }}$ and $\frac{Q_{C D}}{C O P_{A C}}<Q_{H E_{\max }}$. The cooling demand will be completely supplied by the absorption chiller, so that

$Q_{C C}=0$,

and

$E_{\text {grid }}=E_{\mathrm{ED}}-E_{\mathrm{PM}_{\max }}$. ing demand. The boiler will then supply the necessary additional heating. Accordingly, the metered fuel supply will be given by

$F_{m}=F_{P M}+F_{\text {boiler }}=F_{P M}+\left(Q_{\text {bld_D }}-Q_{H E_{\max }}\right) \frac{1}{\eta_{\text {Boiler }}}$.

\subsection{Simulation}

A mid-sized office building was chosen as the building in this study; both the CCHP and the reference system as shown in Figs. 1 and 2 were simulated by using the EnergyPlus software [32]. It is an energy analysis and thermal load simulation program. The user inputs were building dimensions and material properties, along with operational descriptions and assumptions. These inputs were packaged in what is called a model input file. The building chosen in this study is a commercial prototype building model available to the public and was developed by Pacific Northwest National Laboratory. A complete description of the building and assumption can be found along with the input file download [33]. Additionally, TMY3 weather files containing year-long hourly weather data for Chicago, IL were used with input file for EnergyPlus simulation [34]. Based on the input model and weather files, EnergyPlus calculates hourly results for electric, heating and cooling loads necessary to maintain thermal control set points, and the energy consumption of primary plant equipment.

A detailed flow chart showing the simulation process is presented in Fig. 4. The process depicted was carried out in Matlab. After the heating, cooling and electricity demand data were read from the input file, the program iterates for each hour for an entire year. First, the zone of action was chosen from the gross thermal and electrical demand. Then, depending on the value of heating, cooling, and electric demand, the preferred operating condition was selected. All the necessary parameters specified in Table 1 were then computed using the equations mentioned earlier.

The simulation was based on weather data representing Chicago, IL. This reference case was then compared to simulations with CCHP where the prime mover was one of a reciprocating internal combustion engine, a micro-turbine, or a phosphoric acid fuel cell. All three of the prime movers were run with hybrid load following, using the proposed improvement in the relationship between recovered heat and the electricity generated. Each of the three CCHP cases were compared to the reference case in economic performance, energy consumption and emissions according to the parameters outlined in the following section.

\subsection{Performance parameters}

The annual savings of cost, primary energy consumption (PEC) and emissions of carbon dioxide (CDE), nitrogen oxides (NOE) and methane (ME) are explained in this section, and are used to quantify performance of the CCHP system. The annual cost savings is a dollar amount, while the PEC, CDE, NOE and ME savings are given as savings relative to the reference quantities.

\subsubsection{Economic analysis}

The total annual operating cost (AOC) of both the CCHP system and the reference system can be determined by summing for
The remaining recovered heat will be applied toward the heat- each hour during the year the products of metered fuel and grid electricity used with their respective rates. Additionally, the cost of operation and maintenance must be accounted for in the CCHP system.

$$
\begin{aligned}
& A O C_{P M}=\sum_{i=1}^{8760} F_{m_{i}} C_{N G}+E_{\text {grid }_{i}} C_{\text {elec }}+P_{P M_{i}} C_{o m} \\
& A O C_{\text {ref }}=\sum_{i=1}^{8760} F_{m_{\text {ref }}} C_{N G}+E_{\text {grid }_{\text {ref }}} C_{\text {elec }}
\end{aligned}
$$

In the above equations, $C_{N G}$ and $C_{\text {elec }}$ are the cost of natural gas and electricity, respectively. The cost of operation (excluding fuel) and maintenance per unit of energy produced of the PM is $C_{o m}$. The value $P_{P M_{i}}$ is equal to zero when the prime mover is not in use and is equal to $(1 \mathrm{~h} \times$ nominal PM optimum power) during each hour when it is used.

The annual savings is the difference in AOC between the two methods, as indicated in Eq. (69).

$A S=A O C_{r e f}-A O C_{P M}$

This can then be used to calculate the simple payback period (SPP) as [35]

$S P P=\frac{I C}{A S}$,

where IC is the initial cost. This is a simple parameter that provides a rough measure of the value of using a CCHP system. It may be desirable to use a discounted cash flow analysis to obtain a more precise indicator of the performance of the system. One such method is internal rate of return, which indicates the interest rate that would result in the present worth of the cost of the CCHP to be equal to the present worth of the benefits. CCHP is attractive for building operations when IRR $>$ MARR. IRR can be calculated from the equation

$I C=A S\left[\frac{(1+I R R)^{L_{P M}}-1}{I R R(1+I R R)^{L_{P M}}}\right]$,

where $L_{P M}$ is the lifetime of the PM [36]. Another way of representing discounted cash flow analysis is to evaluate the Net Present Value (NPV) for CCHP systems. NPV analysis is important to compare different PM in CCHP systems for an opportunity to reinvest interim cash flow at the net present value discount rate. NPV can be calculated from the equation [37] below

$N P V=\sum_{n=0}^{N} \frac{A S}{(1+i)^{n}}-I C$,

where, $i$ is the discount rate, $n$ is the time of cash flow (period) and $N$ is the total number of periods.

Another analysis that uses discounted cash flow is the equivalent uniform annual savings. First the equivalent uniform annual cost [38] is determined, according to

$E U A C=I C \frac{\xi(1+\xi)^{L_{P M}}}{(1+\xi)^{L_{P M}}-1}$,

where, $\xi$ is the interest rate, chosen as a representative value for bank offered rates. Equivalent uniform annual saving can then be calculated from

$E U A S=E U A C-A S$ power systems based on energy savings, life cycle analysis and environmental consideration, Energy Buildings (2015), http://dx.doi.org/10.1016/j.enbuild.2015.10.047 


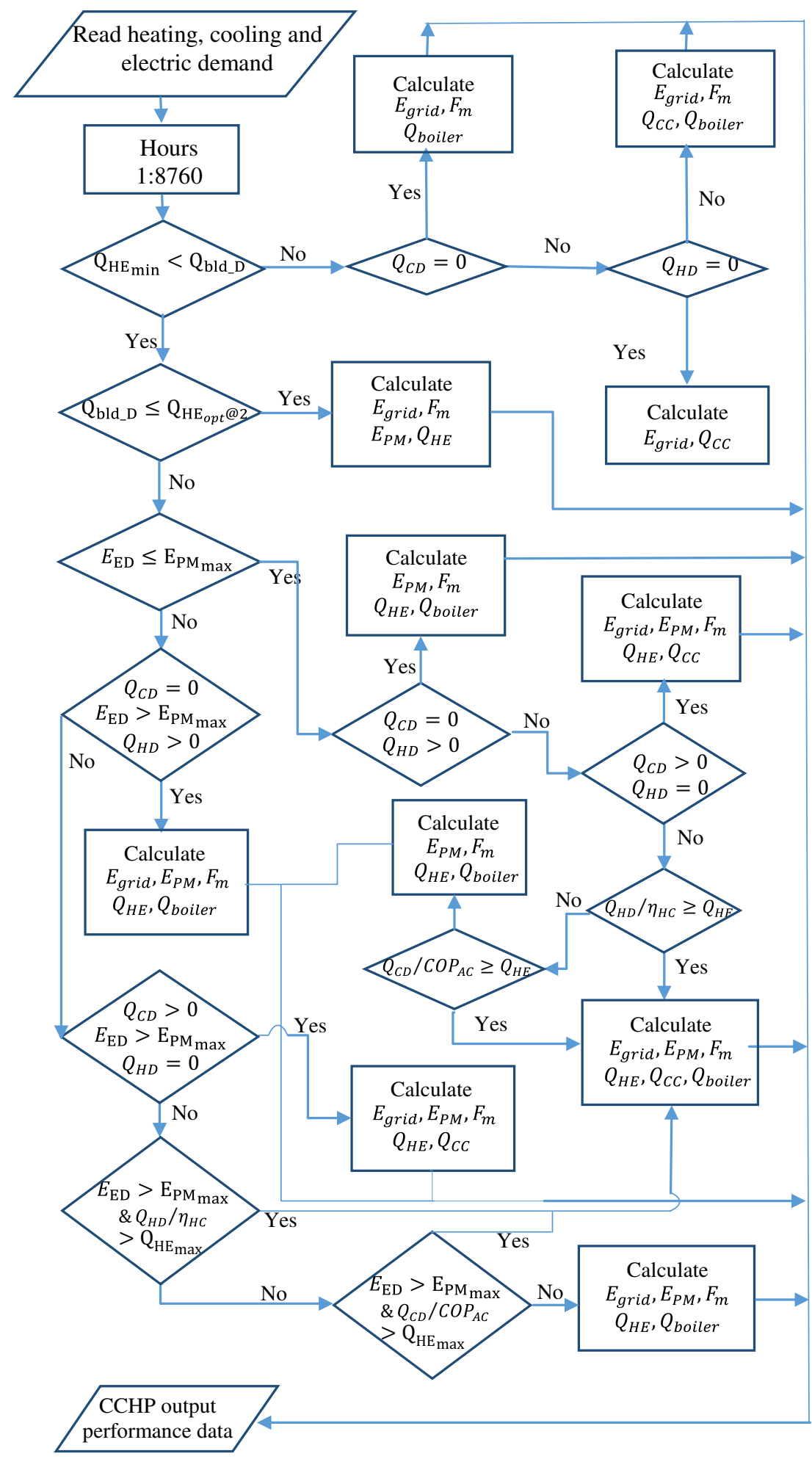

Fig. 4. Flow chart of the CCHP operational method.

\subsubsection{Energy consumption}

Primary energy consumption savings, $P E C_{s}$, are determined relative to the reference system and can be calculated by [29]

$P E C_{s}=\sum_{i=1}^{8760} \frac{\left(F_{m_{\text {ref }_{i}}} P F_{N G}+E_{\text {grid }_{\text {ref }}} P F_{\text {elec }}\right)-\left(F_{m_{i}} P F_{N G}+E_{\text {grid }_{i}} P F_{\text {elec }}\right)}{F_{m_{\text {ref }}} P F_{N G}+E_{\text {grid }_{\text {ref }}} P F_{\text {elec }}}$, where $P F_{\text {elec }}$ and $P F_{N G}$ are the primary energy conversion factors for electricity and natural gas, respectively. Values for this study are given in Table 4.

\subsubsection{Emission characteristics}

The emissions savings are quantified as a reduction in emission relative to the reference system. Reduction in emission refers to the difference in emission of CCHP system from reference system. The

Please cite this article in press as: K. Roman, J. Alvey, Selection of prime mover for combined cooling, heating, and power systems based on energy savings, life cycle analysis and environmental consideration, Energy Buildings (2015), http://dx.doi.org/10.1016/j.enbuild.2015.10.047 
Table 1

Summary of application of hybrid load following method for different prime movers analysis.

\begin{tabular}{|c|c|c|c|c|c|c|c|c|}
\hline Zone & $\begin{array}{l}\text { Operating } \\
\text { conditions }\end{array}$ & $\begin{array}{l}\text { Heating, cooling, } \\
\text { \& electric } \\
\text { demand }\end{array}$ & $Q_{H E}$ & $Q_{\text {boiler }}$ & $F_{m}$ & $Q_{c c}$ & $E_{P M}$ & $E_{\text {grid }}$ \\
\hline \multirow[t]{3}{*}{1} & \multirow[t]{3}{*}{$Q_{H E_{\min }}>Q_{b l d_{-} D}$} & $\begin{array}{l}Q_{C D}=0 \\
Q_{H D}>0 \\
E_{E D}>0\end{array}$ & 0 & $\frac{Q_{H D}}{\eta_{H C}}$ & $F_{\text {boiler }}$ & 0 & 0 & $E_{\mathrm{ED}}$ \\
\hline & & $\begin{array}{l}Q_{C D}>0 \\
Q_{H D}=0 \\
E_{E D}>0\end{array}$ & 0 & 0 & 0 & $Q_{C D}$ & 0 & $E_{\mathrm{ED}}+\frac{Q_{C D}}{{ }^{C O P_{C C}}}$ \\
\hline & & $\begin{array}{l}Q_{C D}>0 \\
Q_{H D}>0 \\
E_{\mathrm{ED}}>0\end{array}$ & 0 & $\frac{Q_{H D}}{\eta_{H C}}$ & $F_{\text {boiler }}$ & $Q_{C D}$ & 0 & $E_{\mathrm{ED}}+\frac{Q_{C D}}{\operatorname{COP}_{C C}}$ \\
\hline \multirow[t]{2}{*}{2} & $\begin{array}{l}Q_{H E_{\min }} \leq Q_{\text {bld_D }} \\
Q_{\text {bld_D }} \leq \\
Q_{H E_{\text {opt }} @ 2}\end{array}$ & $\begin{array}{l}Q_{C D} \geq 0 \\
Q_{H D} \geq 0 \\
E_{\mathrm{ED}}>0\end{array}$ & $\frac{Q_{H D}}{\eta_{H C}}+\frac{Q_{C D}}{C_{C P}}$ & 0 & $F_{P M}$ & 0 & $E_{P M @ 2^{\prime}}$ & $E_{\mathrm{ED}}-E_{\mathrm{PM} @ 2^{\prime}}$ \\
\hline & \multirow{5}{*}{$\begin{array}{l}Q_{H E_{\min }} \leq Q_{b l d_{-} D} \\
Q_{b l d_{D}}>Q_{H E_{\text {opt }} @ 3} \\
E_{E D} \leq E_{P M_{\max }}\end{array}$} & $\begin{array}{l}Q_{C D}=0 \\
Q_{H D}>0 \\
E_{\mathrm{ED}}>0\end{array}$ & $E_{\mathrm{ED}}^{2}+\beta E_{\mathrm{ED}}+\gamma$ & $\frac{Q_{H D}}{\eta_{H C}}-Q_{H E}$ & $F_{P M}+F_{\text {boiler }}$ & 0 & $E_{\mathrm{ED}}$ & 0 \\
\hline \multirow{5}{*}{3} & & $\begin{array}{l}Q_{C D}>0 \\
Q_{H D}=0 \\
E_{\mathrm{ED}}>0\end{array}$ & $\alpha E_{\mathrm{ED}}^{2}+\beta E_{\mathrm{ED}}+\gamma$ & 0 & $F_{P M}$ & $Q_{C D}-Q_{A C}$ & $E_{\mathrm{ED}}$ & $\frac{Q_{C C}}{C_{C C}}$ \\
\hline & & $\begin{array}{l}\frac{Q_{H D}}{\eta_{H C}} \geq Q_{H E} \\
E_{\mathrm{ED}}>0\end{array}$ & $\alpha E_{\mathrm{ED}}^{2}+\beta E_{\mathrm{ED}}+\gamma$ & $\frac{Q_{H D}}{\eta_{H C}}-Q_{H E}$ & $F_{P M}+F_{\text {boiler }}$ & $Q_{C D}$ & $E_{\mathrm{ED}}$ & $\frac{Q_{C D}}{C_{C C}}$ \\
\hline & & $\begin{array}{l}\frac{Q_{C D}}{C O P_{A C}} \geq Q_{H E} \\
E_{\mathrm{ED}}>0\end{array}$ & $\alpha E_{\mathrm{ED}}^{2}+\beta E_{\mathrm{ED}}+\gamma$ & $\frac{Q_{H D}}{\eta_{H C}}$ & $F_{P M}+F_{\text {boiler }}$ & $Q_{C D}-Q_{A C}$ & $E_{\mathrm{ED}}$ & $\frac{Q_{C C}}{{ }_{C O P}}$ \\
\hline & & $\begin{array}{l}\frac{Q_{C D}}{C O P_{A C}}<Q_{H E} \text { and } \\
\frac{Q_{H D}}{\eta_{H C}}<Q_{H E}\end{array}$ & $\alpha E_{\mathrm{ED}}^{2}+\beta E_{\mathrm{ED}}+\gamma$ & $Q_{b l d D}-Q_{H E}$ & $F_{P M}+F_{\text {boiler }}$ & 0 & $E_{\mathrm{ED}}$ & 0 \\
\hline & \multirow{5}{*}{$\begin{array}{l}Q_{H E_{\max }}<Q_{b l d \_D} \\
E_{E D}>E_{P M_{\max }}\end{array}$} & $\begin{array}{l}Q_{C D}=0 \\
Q_{H D}>0 \\
E_{E D}>E_{P M_{\max }}\end{array}$ & $Q_{H E \max }$ & $\frac{Q_{H D}}{\eta_{H C}}-Q_{H E \max }$ & $F_{P M}+F_{\text {boiler }}$ & 0 & $E_{P M_{\max }}$ & $E_{\mathrm{ED}}-E_{P M_{\max }}$ \\
\hline \multirow{4}{*}{4} & & $\begin{array}{l}Q_{C D}>0 \\
Q_{H D}=0 \\
E_{E D}>E_{P M_{\max }}\end{array}$ & $Q_{H E_{\max }}$ & 0 & $F_{P M}$ & $Q_{C D}-Q_{A C}$ & $E_{P M_{\max }}$ & $\frac{Q_{C C}}{{ }^{C O P} P_{C C}}+E_{\mathrm{ED}}-E_{P M_{\max }}$ \\
\hline & & $\begin{array}{l}\frac{Q_{H D}}{\eta_{H C}}>Q_{H E_{\max }} \\
E_{E D}>E_{P M_{\max }}\end{array}$ & $Q_{H E \max }$ & $\frac{Q_{H D}}{\eta_{H C}}-Q_{H E_{\max }}$ & $F_{P M}+F_{\text {boiler }}$ & $Q_{C D}$ & $E_{P M_{\max }}$ & $\frac{Q_{\mathrm{CC}}}{\operatorname{COP}_{\mathrm{CC}}}+E_{\mathrm{ED}}-E_{P M_{\max }}$ \\
\hline & & $\begin{array}{l}\frac{Q_{C D}}{C O P_{A C}}>Q_{H E_{\max }} \\
E_{E D}>E_{P M_{\max }}\end{array}$ & $Q_{H E \max }$ & $\frac{Q_{H D}}{\eta_{H C}}$ & $F_{P M}+F_{\text {boiler }}$ & $Q_{C D}-Q_{A C}$ & $E_{P M_{\max }}$ & $\frac{Q_{C C}}{{ }^{C O P_{C C}}}+E_{\mathrm{ED}}-E_{P M_{\max }}$ \\
\hline & & $\begin{array}{l}\frac{Q_{H D}}{\eta_{H C}}<Q_{H E_{\max }} \\
\text { and } \\
\frac{Q_{C D}}{C^{C O P} P_{A C}}<Q_{H E_{\max }}\end{array}$ & $Q_{H E_{\max }}$ & $Q_{b l d D}-Q_{H E}$ & $F_{P M}+F_{\text {boiler }}$ & 0 & $E_{P M_{\max }}$ & $E_{\mathrm{ED}}-E_{P M_{\max }}$ \\
\hline
\end{tabular}

equations for all three gasses considered in this study are similar and are represented by [6]:

$E m_{s, g}=\sum_{i=1}^{8760} \frac{E m_{r e f_{i}}-E m_{C C H P_{i}}}{E m_{r e f_{i}}}$.

Here the $g$ in the subscripts represents the gas for which the savings are being calculated. Thus $E m_{s, g}$ represents the emission savings for carbon dioxide $(g=C D)$, nitrogen oxides $(g=N X)$ and methane $(g=M) . E m_{r e f}$ are the emissions from the reference case and $E m_{C C H P}$ are the emissions obtained when CCHP system is operated and can be calculated by

$E m_{C C H P}=F_{m} E F_{N G, g}+E_{\text {grid }} E F_{\text {elec }, g}$

$E m_{\text {ref }}=F_{m_{\text {ref }}} E F_{N G, g}+E_{\text {grid }_{\text {ref }}} E F_{\text {elec }, g}$

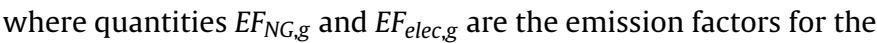
respective gases for natural gas and electric sources respectively, with values given in Table 4 . The amount of $\mathrm{CO}_{2}, \mathrm{NO}_{x}$, and $\mathrm{CH}_{4}$ emissions can be determined by using the emission conversion factors listed in Table 4. These emission conversion factors depend on the location of the PM installed and the fuel type used to generate the electricity. The emission caused by the reference system is due to the electricity generation by power plant that is supplied to the grid and the local boiler that is used to produce heat. The emission caused by CCHP is due to electricity produced by the CCHP systems,
Table 2

Design specifications for CCHP simulation program.

\begin{tabular}{lll}
\hline Variable & Symbol & Value \\
\hline Compression chiller coefficient of performance & $C O P_{C C}$ & 3 \\
Absorption chiller coefficient of performance & $C O P_{A C}$ & 0.85 \\
Boiler efficiency & $\eta_{B o i l e r}$ & 0.83 \\
Heating coil efficiency & $\eta_{H C}$ & 0.85 \\
Heat exchanger efficiency & $\eta_{H E}$ & 0.85 \\
Factor of heat losses from prime mover to heat exchanger & $\psi$ & 0.95 \\
\hline
\end{tabular}

electricity generation process of the power plant and heat produced by the boiler.

\section{Discussion}

The methods described in Section 2 were implemented in simulations for a medium size office building in Chicago, IL, which represents a cold and humid climate. Simulations were implemented for 1 year durations on an hourly basis for each of the prime movers listed in Table 3. Assumptions were made for the CCHP system based on typical efficiency values found in ASHRAE Handbook [39] and previous optimization studies $[4,40]$. The components for the CCHP system were prescribed the efficiencies, coefficients of performance and factor of heat loss given in Table 2. Costs, emission rates and PEC factors for natural gas and electricity for the selected city are listed in Table 4 . The building demands for

Please cite this article in press as: K. Roman, J. Alvey, Selection of prime mover for combined cooling, heating, and power systems based on energy savings, life cycle analysis and environmental consideration, Energy Buildings (2015), http://dx.doi.org/10.1016/j.enbuild.2015.10.047 


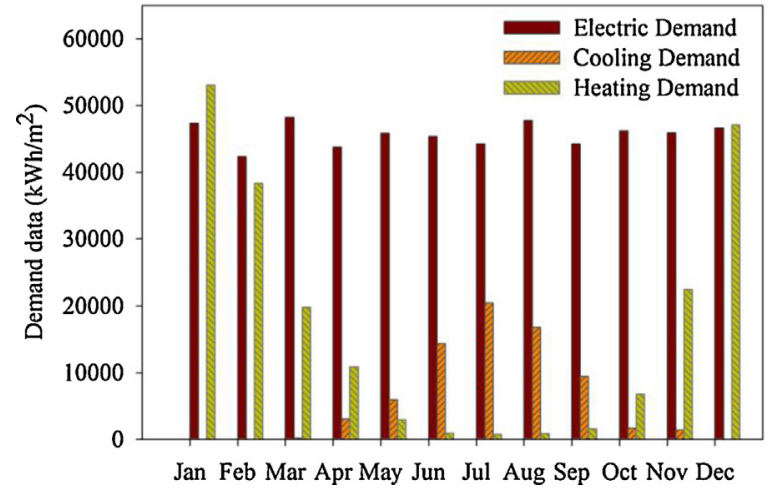

Fig. 5. Building cooling, heating, and electric load demand per month for Chicago.

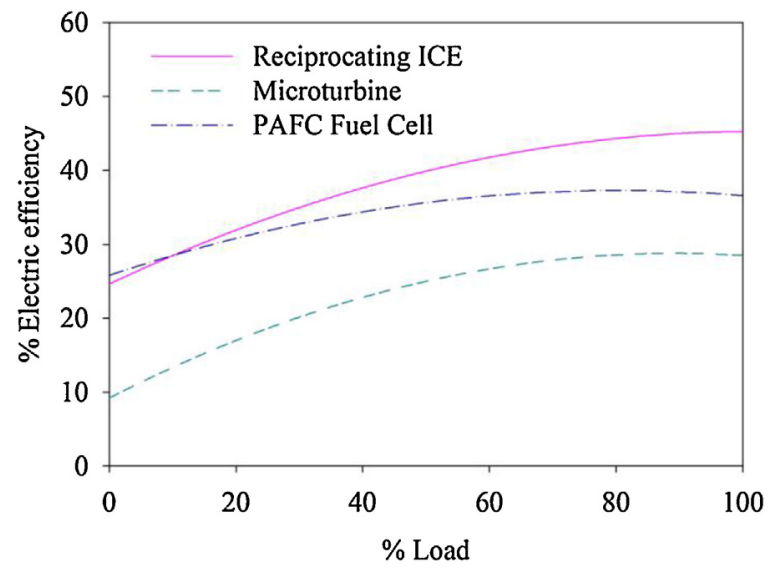

Fig. 6. Comparison of part load efficiency of different prime mover [31].

cooling, heating and electric loads used in the simulation are graphically represented by month in Fig. 5, which were obtained from the EnergyPlus simulation output.

\subsection{Sizing of prime mover}

Fig. 6 represents manufacturer data for efficiency vs. partial load of the prime movers. This is the data that is used to determine the coefficients $a, b$ and $c$ that come from Eq. (7), shown in Table 3 for each prime mover. Table 3 also shows the capital costs, operation and maintenance costs, and lifetimes of all three prime movers. These values are used to compute the EUAS, as described in Section 2.3.1, for a range of nominal power capacities. The optimum nominal power can be determined from these results, as illustrated in Fig. 7 for a reciprocating internal combustion engine. A nominal value of $30 \mathrm{~kW}$ was selected for all three prime movers, in order to provide more direct comparison, based on the optimum capacity for the internal combustion engine.

\subsection{Economic analysis}

The economic performance parameters of the three different types of prime movers are summarized in Table 5. Positive values of SPP, IRR, NPV, EUAS, and AS indicate that CCHP system has the potential to satisfy the building energy demands by integrating it with the electric grid whereas negative values indicate that CCHP system increase the financial burden to the building owner. Overall, the reciprocating ICE provides the best economic advantage. The simple payback period was found to be 5.9 years for the ICE, 7.8 years for the micro-turbine, and 28.4 years for the fuel cell. The ICE also gave the best IRR, at 17\%. The micro-turbine gave a 9\% IRR,

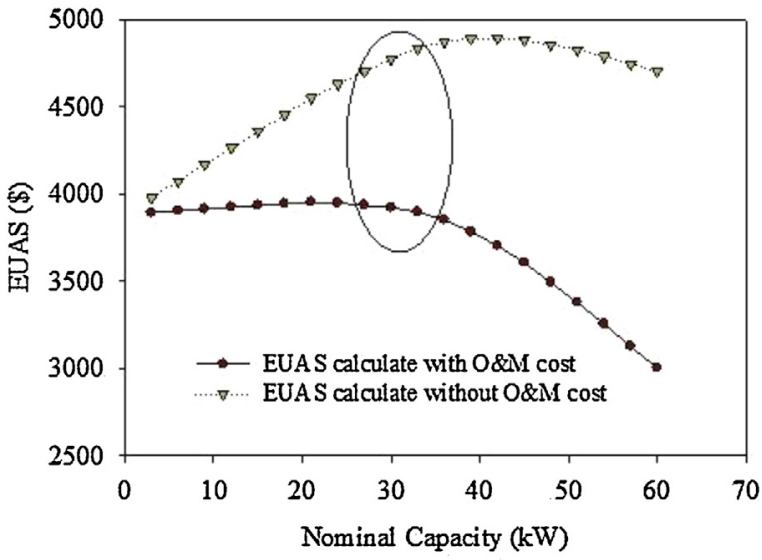

Fig. 7. Nominal power optimization of reciprocating internal combustion engine.

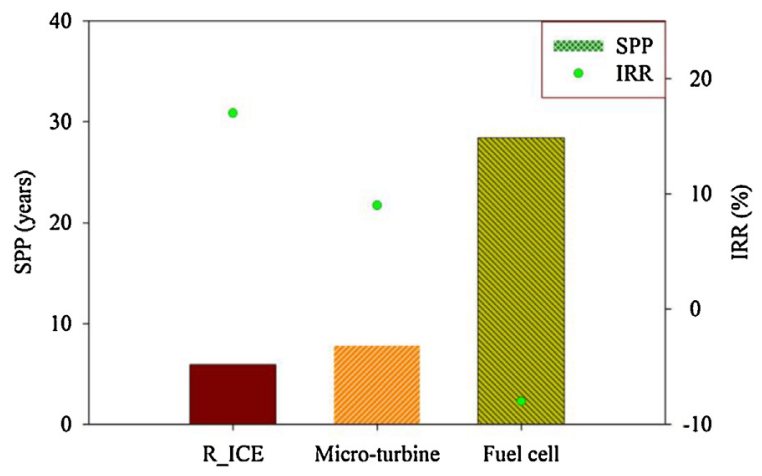

Fig. 8. SPP and IRR comparison of CCHP installed building in Chicago.

while the fuel cell resulted in a negative rate of return, $-8 \%$ IRR. All three prime movers have similar annual savings, calculated to be $\$ 6281, \$ 7132$, and $\$ 5804$ for the ICE, the fuel cell, and the microturbine respectively. The NPV analysis had similar results. For NPV analysis we have used discount rate as $10 \%$; it can be defined as an opportunity cost of the capital that a business can earn on an investment from the financial markets with similar risk. The ICE had the best NPV at $\$ 21,456$ and the micro-turbine had a modest value at $\$ 3330$. The fuel cell, however, had a negative NPV an order of magnitude greater than the positive value for the ICE. When equivalent uniform annual savings is considered, however, the results are very different. The results for the ICE and micro-turbine are similar with EUAS of $\$ 4052$ and $\$ 2800$ respectively, while the fuel cell has a negative EUAS. These results indicate that from an economic perspective, the ICE is the most attractive option, while the microturbine is a reasonable choice for prime mover. The fuel cell would result in net losses over the lifetime of the system and thus should be avoided. With the lowest SPP and highest IRR (see Fig. 8) and $\mathrm{NPV}$, the ICE is the best economic choice for the studied building type and location.

Selecting a new PM for CCHP over a reference system is not always a straight forward evaluation, PM selection generally is based on economical parameters (SPP, IRR, NPV, EUAS, and AS) analysis. However, it might also depend on the specific project particularity, such as budget restriction, energy saving credits, capital incentives for installing any particular type of PM systems. Investors or building owner can choose the optimum PM by its own criteria. For example, from Table 5 it is obvious that fuel cell might incur significant financial burden to the project with all its negative economic parameters (except AS and SPP). However it could
530

Please cite this article in press as: K. Roman, J. Alvey, Selection of prime mover for combined cooling, heating, and power systems based on energy savings, life cycle analysis and environmental consideration, Energy Buildings (2015), http://dx.doi.org/10.1016/j.enbuild.2015.10.047 
Table 3

Performance parameters and cost for different prime mover.

\begin{tabular}{|c|c|c|c|c|c|c|}
\hline \multirow[t]{2}{*}{ Prime mover } & \multicolumn{3}{|c|}{$F_{P M}=a E_{P M}^{2}+b E_{P M}+c[31]$} & \multirow[t]{2}{*}{ Capital cost $[41](\$ / \mathrm{kW})$} & \multirow[t]{2}{*}{$\mathrm{O} \& \mathrm{M}$ cost $[41](\$ / \mathrm{kWh})$} & \multirow[t]{2}{*}{ Equipment life [42-44] (h) } \\
\hline & $a$ & $b$ & $c$ & & & \\
\hline Reciprocating ICE & $-9.05 e-3$ & 2.62 & 5.53 & 1225 & 0.027 & 60,000 \\
\hline Micro-turbine & -0.0120 & 3.71 & 21.21 & 1850 & 0.014 & 40,000 \\
\hline PAFC Fuel Cell & -0.0021 & 2.71 & 4.96 & 5500 & 0.036 & 50,000 \\
\hline
\end{tabular}

Table 4

Cost of fuel, electricity and emission and PEC factors for Chicago.

\begin{tabular}{|c|c|c|c|c|}
\hline Variable & Symbol & Value & Unit & Reference \\
\hline Electric cost & $C_{\text {elec }}$ & 0.0757 & $\$ / \mathrm{kWh}$ & [45] \\
\hline Natural gas cost & $C_{N G}$ & 0.0125 & $\$ / \mathrm{kWh}$ & [46] \\
\hline Electric $\mathrm{CO}_{2}$ emission & $E F_{\text {elec }, C D}$ & 0.682 & $\mathrm{~kg} / \mathrm{kWh}$ & [47] \\
\hline Natural gas $\mathrm{CO}_{2}$ emission & $E F_{N G, C D}$ & 0.181 & $\mathrm{~kg} / \mathrm{kWh}$ & \\
\hline Electric $\mathrm{NO}_{\mathrm{x}}$ emission & $E F_{\text {elec }, N X}$ & $1.12 \times 10^{-5}$ & $\mathrm{~kg} / \mathrm{kWh}$ & \\
\hline Natural gas $\mathrm{NO}_{\mathrm{x}}$ emission & $E F_{N G, N X}$ & $8.54 \times 10^{-7}$ & $\mathrm{~kg} / \mathrm{kWh}$ & \\
\hline Electric $\mathrm{CH}_{4}$ emission & $E F_{\text {elec }, M}$ & $8.26 \times 10^{-6}$ & $\mathrm{~kg} / \mathrm{kWh}$ & \\
\hline Natural gas $\mathrm{CH}_{4}$ emission & $E F_{N G, M}$ & $1.17 \times 10^{-8}$ & $\mathrm{~kg} / \mathrm{kWh}$ & \\
\hline Electric PEC factor & $P F_{\text {elec }}$ & 3.5 & - & [48] \\
\hline Natural gas PEC factor & $P F_{N G}$ & 1.09 & - & \\
\hline
\end{tabular}

Table 5

Economic analysis for $30 \mathrm{~kW}$ prime mover implemented in office building in Chicago.

\begin{tabular}{|c|c|c|c|c|c|}
\hline Variable & Symbol & Unit & Reciprocating ICE & Micro-turbine & Fuel cell \\
\hline Simple payback period & SPP & Years & 5.9 & 7.8 & 28.4 \\
\hline Internal rate of return & IRR & $\%$ & 17 & 9 & -8 \\
\hline Net present value & $N P V$ & $\$$ & 21,456 & 3330 & $-113,532$ \\
\hline Equivalent uniform annual saving & EUAS & $\$$ & 4052 & 2800 & -1978 \\
\hline Annual operating cost saving & AS & $\$$ & 6281 & 7132 & 5804 \\
\hline
\end{tabular}

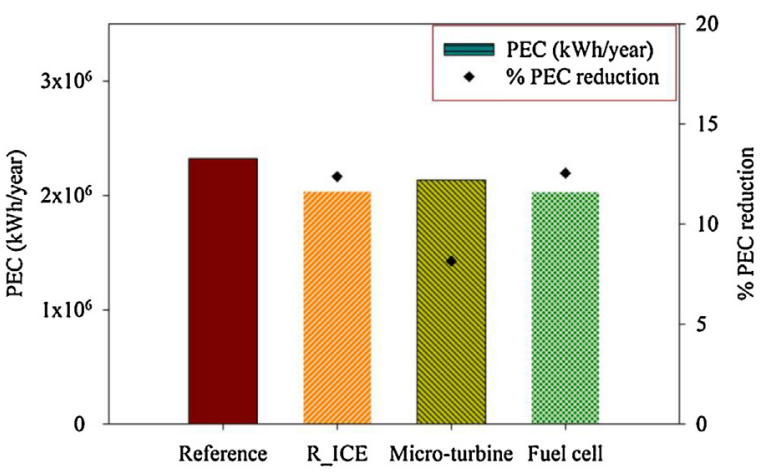

Fig. 9. PEC comparison of reference office building with CCHP installed building in Chicago.

still be a good investment with favorable capital incentives, which sometimes offered by different government entities.

\subsection{Primary energy consumption analysis}

The site energy consumption will increase when cogeneration is used, as shown by Fumo et al. [28], and thus the primary energy consumption is a better parameter to use in analyzing energy benefits of such a system. Table 6 and Fig. 9 summarize the results of the energy analysis for PEC savings. The reciprocating ICE and fuel cell prime movers had comparable PEC savings, at $12.4 \%$ and $12.5 \%$ respectively, while the micro-turbine showed PEC savings of 8.1\%. All three options for prime mover provide significant energy savings. If the economic analysis is neglected and only the energy consumption considered, all three prime movers would be good options.

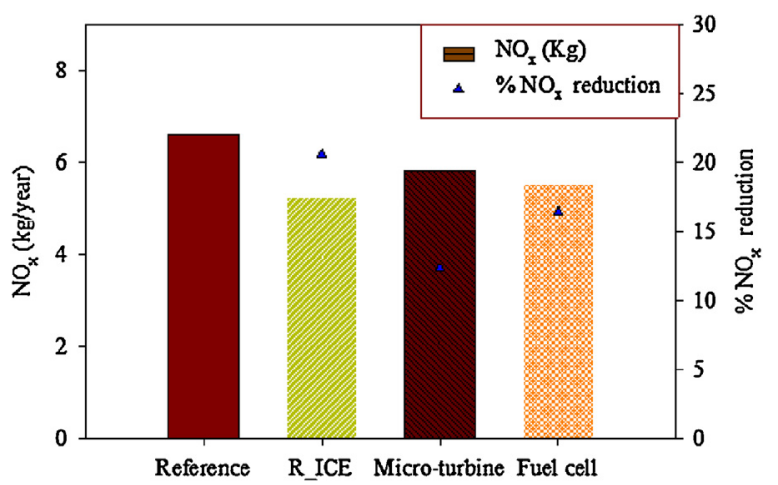

Fig. 10. $\mathrm{NO}_{x}$ comparison of reference office building with CCHP installed building in Chicago.

\subsection{Emission analysis}

The final important factor to the implementation of a CCHP system is the effect it has on emissions. If the system were to save in cost and energy, but still somehow lead to an increase in emissions, the system would not be altogether beneficial to implement. Table 7 and Figs. 10-12 summarize the results for the three prime movers for each of the three gases evaluated. The reciprocating ICE gave reductions in emissions of $14.4 \%$ for carbon dioxide, $20.5 \%$ for nitrogen oxides, and $23.1 \%$ for methane. The micro-turbine had reductions in emissions of $9.3 \%$ for carbon dioxide, $12.3 \%$ for nitrogen oxides, and $13.4 \%$ for methane. The fuel cell showed reductions in emissions of $13.5 \%$ for carbon dioxide, $16.4 \%$ for nitrogen oxides, and $17.3 \%$ for methane. The simulations for all three types of prime movers indicate that they would all provide significant savings in emissions of carbon dioxide, nitrogen oxides, and methane. The results show that for the selected building and climate zone, the ICE has significantly better savings that the micro-turbine and fuel

Please cite this article in press as: K. Roman, J. Alvey, Selection of prime mover for combined cooling, heating, and power systems based on energy savings, life cycle analysis and environmental consideration, Energy Buildings (2015), http://dx.doi.org/10.1016/j.enbuild.2015.10.047 
Table 6

Energy analysis for $30 \mathrm{~kW}$ prime mover implemented in office building in Chicago.

\begin{tabular}{|c|c|c|c|c|c|c|}
\hline Variable & Symbol & Unit & Reference & Reciprocating ICE & Micro-turbine & Fuel cell \\
\hline Primary energy consumption & PEC & kWh/year & $2.322 \times 10^{6}$ & $2.035 \times 10^{6}$ & $2.133 \times 10^{6}$ & $2.031 \times 10^{6}$ \\
\hline
\end{tabular}

Table 7

$\mathrm{CO}_{2}, \mathrm{NO}_{x}$, and $\mathrm{CH}_{4}$ emission parameters from an office building in Chicago.

\begin{tabular}{|c|c|c|c|c|c|c|}
\hline Variable & Symbol & Unit & Reference & Reciprocating ICE & Micro-turbine & Fuel cell \\
\hline Carbon dioxide emission & $C D E$ & Tons/year & 524.55 & 448.8 & 475.9 & 453.8 \\
\hline Nitrogen oxides emission & $N X E$ & & 0.0073 & 0.0058 & 0.0064 & 0.0061 \\
\hline Methane emission & $M E$ & & 0.0052 & 0.0040 & 0.0045 & 0.0043 \\
\hline
\end{tabular}

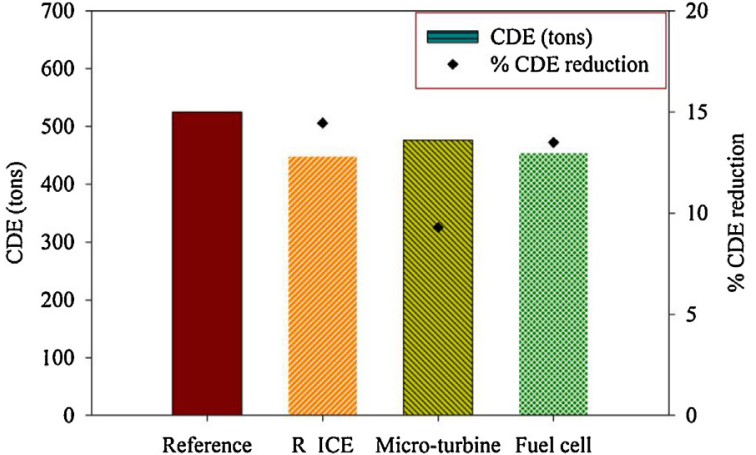

Fig. 11. CDE comparison of reference office building with CCHP installed building in Chicago.

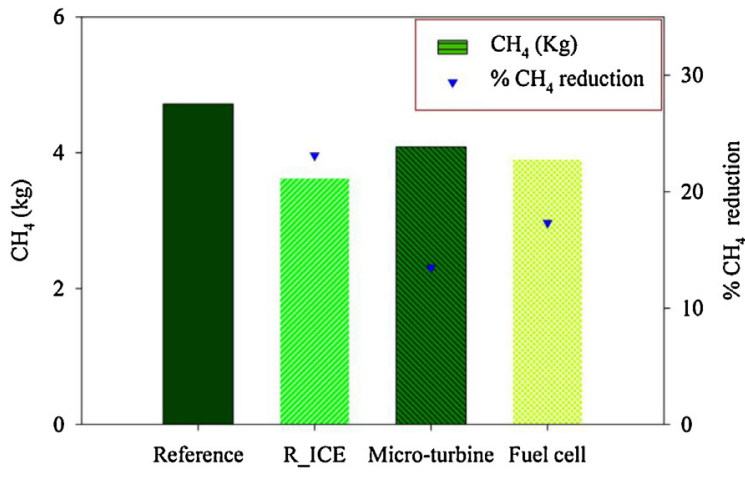

Fig. 12. $\mathrm{CH}_{4}$ comparison of reference office building with $\mathrm{CCHP}$ installed building in Chicago.

cell prime movers, while the fuel cell prime mover has slightly better savings than the micro-turbine. All three options will provide savings in emissions, but the best option is the ICE for the emission parameters.

Emission saving can also be quantified in terms of economic benefit especially when building owners have the opportunity to claim carbon credit provided that government authorities (federal, state or local energy department) have some established emission saving incentives in practice. Carbon credit might offset the negative EUAS to an economically attractive venture. For example, Fuel cell reduces carbon dioxide emission by 70.75 tons/year and to offset the negative EUAS (EUAS > 0) to an economically feasible CCHP system, a minimum of carbon credit of approximately $\$ 27.95 /$ tons of carbon dioxide is required yearly.

The above results all combine to give a complete picture of the feasibility of each of the prime mover types considered in this study. Table 5 and Fig. 8 clearly show that the fuel cell is not a viable option due to the expected loss of money from implementation. Although the fuel cell has comparable energy consumption and emissions savings to the other two options, it is not economically feasible. Further discussion will focus on the ICE and micro-turbine options. Table 6 and Fig. 9 together show that a reduction in primary energy consumption will occur in the implementation of both the ICE and the micro-turbine. We can see that the reduction is more significant for the ICE. Now considering emissions savings, we can see from Table 7 and Figs. 10-12 that, similar to energy consumption, the emissions savings of both the ICE and the micro-turbine are comparable. Again, the ICE has more significant savings than the micro-turbine. Ultimately, the best choice for prime mover, for the chosen building and location in this study, is the ICE.

\section{Conclusion}

A method for the selection of prime mover is introduced, based on economic, energy consumption and emissions criteria. Simulations were run for a mid-sized office building located in a cold and humid climate (Chicago, IL) for a reciprocating internal combustion engine, a mirco-turbine and a phosphoric acid fuel cell by using a hybrid load following scheme. The results were compared to the reference building which has separate heating and power system. This evaluation study explored the selection of a PM by scheduling their operation in an optimum manner, and reducing building life cycle cost significantly. Results indicate emissions reductions for all three types of prime movers, with the most reduction from the ICE followed by the fuel cell, then the micro turbine. Prime energy consumption was also shown to be reduced for all three cases, with the most reduction from the fuel cell followed closely by the ICE, then the micro turbine. Economic considerations, however, indicate that the fuel cell PM would not be feasible. The ICE would have the best economic savings, followed by the mirco-turbine. The results indicate that positive results in one of these important performance areas will not always coincide with positive results of others. For a design to be feasible, it should indicate positive results in all three of the performance areas. As a general guideline for any evaluated building, when any of the economic parameters from IRR, NPV or EUAS are negative, it is unlikely for the building owner to invest even when emission or energy consumption are still showing considerable amount of improvement. However CCHP could still be an attractive investment with negative life cycle parameters when federal, state, or local authorities effectively implemented the favorable energy efficiency policies and offered incentives like tax deductions, carbon credit, etc. to the building owner for implementing this in a building.

It is worth noting that this current study focused on selecting a PM by simulating different case scenario for a hybrid load following strategy, however for practical implementation, once the PM is selected it is necessary to further study the optimum PM capacity, and to integrate the simulation with a real time energy management system.

It is envisioned that the results obtained in this paper will be a valuable source of information for researchers, designers and

Please cite this article in press as: K. Roman, J. Alvey, Selection of prime mover for combined cooling, heating, and power systems based on energy savings, life cycle analysis and environmental consideration, Energy Buildings (2015), http://dx.doi.org/10.1016/j.enbuild.2015.10.047 
engineers; and will provide direction and guidance for future research in CCHP technology. This study was conducted for a certain type of building within a certain climate zone; according to US department of Energy (DOE), there are 16 climate zones around the country. Also DOE has developed 16 reference building types that represent approximately $70 \%$ of the commercial buildings in US. Future studies may include carrying out this methodology for different climate zones and building types, which may prove useful for the optimization of CCHP design under various conditions in the near future.

\section{Acknowledgements}

The authors express their gratitude to the reviewers for their thoughtful feedback, which was used to improve the quality of the paper.

\section{References}

[1] US Department of Energy, FACT SHEET: Energy Department Actions to Deploy Combined Heat and Power, Boost Industrial Efficiency, Department of Energy, 2013.

[2] J. Wang, J. Sui, H. Jin, An improved operation strategy of combined cooling heating and power system following electrical load, Energy (2015) 1-13.

[3] H. Mu, L. Li, N. Li, M. Li, Analysis of the integrated performance and redundant energy of CCHP systems under different operation strategies, Energy Build. (2015).

[4] A.D. Smith, P.J. Mago, Effects of load-following operational methods on combined heat and power system efficiency, Appl. Energy 115 (February) (2014) 337-351.

[5] P.J. Mago, R. Luck, Evaluation of a base-loaded combined heating and power system with thermal storage for different small building applications, Int. J. Energy Res. vol. 37 (February (2)) (2013) 179-188.

[6] P.J. Mago, R. Luck, A. Knizley, Combined heat and power systems with dual power generation units and thermal storage, Int. J. Energy Res. 38 (June (7)) (2014) 896-907.

[7] US Department of Energy, Combined Heat and Power: A Clean Energy Solution, 2012

[8] P.J. Mago, R. Luck, Prime mover sizing for base-loaded combined heating and power systems, Proc. Inst. Mech. Eng. A: J. Power Energy 226 (October (1)) (2011) 17-27.

[9] K.C. Kavvadias, A.P. Tosios, Z.B. Maroulis, Design of a combined heating, cooling and power system: sizing, operation strategy selection and parametric analysis, Energy Convers. Manag. 51 (April (4)) (2010) 833-845.

[10] A.a. Knizley, P.J. Mago, A.D. Smith, Evaluation of the performance of combined cooling, heating, and power systems with dual power generation units, Energy Policy 66 (2014) 654-665.

[11] P.J. Mago, L.M. Chamra, J. Ramsay, Micro-combined cooling, heating and power systems hybrid electric-thermal load following operation, Appl. Therm. Eng. 30 (8-9) (2010) 800-806.

[12] M. Ebrahimi, A. Keshavarz, Sizing the prime mover of a residential micro-combined cooling heating and power (CCHP) system by multi-criteria sizing method for different climates, Energy 54 (June) (2013) 291-301.

[13] A.N. Ünal, S. Ercan, G. Kayakutlu, Optimisation studies on tri-generation: a review, Int. J. Energy Res. (2015).

[14] a. Piacentino, R. Gallea, F. Cardona, V. Lo Brano, G. Ciulla, P. Catrini, Optimization of trigeneration systems by mathematical programming: influence of plant scheme and boundary conditions, Energy Convers. Manag. (2015).

[15] H. Hajabdollahi, A. Ganjehkaviri, M.N.M. Jaafar, Assessment of new operational strategy in optimization of CCHP plant for different climates using evolutionary algorithms, Appl. Therm. Eng. 75 (2015) 468-480.

[16] P.J. Mago, L.M. Chamra, Analysis and optimization of CCHP systems based on energy, economical, and environmental considerations, Energy Build. 41 (October (10)) (2009) 1099-1106.

[17] D. Steen, M. Stadler, G. Cardoso, M. Groissböck, N. DeForest, C. Marnay, Modeling of thermal storage systems in MILP distributed energy resource models, Appl. Energy 137 (January) (2015) 782-792.

[18] N. DeForest, G. Mendes, M. Stadler, W. Feng, J. Lai, C. Marnay, Optimal deployment of thermal energy storage under diverse economic and climate conditions, Appl. Energy 119 (April) (2014) 488-496.

[19] Y. Zhao, Y. Lu, C. Yan, S. Wang, MPC-based optimal scheduling of grid-connected low energy buildings with thermal energy storages, Energy Build. 86 (January) (2015) 415-426.
[20] S. Sanaye, M.A. Meybodi, S. Shokrollahi, Selecting the prime movers and nominal powers in combined heat and power systems, Appl. Therm. Eng. 28 (10) (2008) 1177-1188.

[21] D. Sree, T. Paul, H. Aglan, Temperature and power consumption measurements as a means for evaluating building thermal performance, Appl. Energy 87 (6) (2010) 2014-2022.

[22] N. Bizon, M. Oproescu, M. Raceanu, Efficient energy control strategies for a standalone renewable/fuel cell hybrid power source, Energy Convers. Manag. 90 (2015) 93-110.

[23] L. Yang, E. Entchev, M. Ghorab, E.J. Lee, E.C. Kang, Energy and cost analyses of a hybrid renewable microgeneration system serving multiple residential and small office buildings, Appl. Therm. Eng. 65 (April (1-2)) (2014) $477-486$.

[24] C.T. Yücer, A. Hepbasli, Exergoeconomic and enviroeconomic analyses of a building heating system using SPECO and Lowex methods, Energy Build. 73 (April) (2014) 1-6.

[25] M.T. Balta, I. Dincer, A. Hepbasli, Performance and sustainability assessment of energy options for building HVAC applications, Energy Build. 42 (August (8)) (2010) 1320-1328.

[26] E. Açıkkalp, A. Hepbasli, C.T. Yucer, T.H. Karakoc, Advanced exergoenvironmental assessment of a building from the primary energy transformation to the environment, Energy Build. 89 (February) (2015) $1-8$.

[27] E. Açıkkalp, C.T. Yucer, A. Hepbasli, T.H. Karakoc, Advanced low exergy (ADLOWEX) modeling and analysis of a building from the primary energy transformation to the environment, Energy Build. 81 (October) (2014) 281-286.

[28] N. Fumo, P.J. Mago, L.M. Chamra, Analysis of cooling, heating, and power systems based on site energy consumption, Appl. Energy 86 (June (6)) (2009) 928-932.

[29] P.J. Mago, L.M. Chamra, J. Ramsay, Micro-combined cooling, heating and power systems hybrid electric-thermal load following operation, Appl Therm. Eng. 30 (June (8-9)) (2010) 800-806.

[30] A.K. Hueffed, P.J. Mago, Energy, economic, and environmental analysis of combined heating and power-organic Rankine cycle and combined cooling, heating, and power-organic Rankine cycle systems', Proc Inst. Mech. Eng. A: J. Power Energy 225 (February (1)) (2011) 24-32.

[31] Catalog of CHP Technologies, U.S. Environmental Protection Agency, Combined Heat and Power Partnership, 2015.

[32] EnergyPlus Energy Simulation Software, EnergyPlus 8.0, 2014, Available: http://apps1.eere.energy.gov/buildings/energyplus (accessed 26.02.15) (Online).

[33] "Existing Commercial Reference Buildings Constructed in or After 1980," Office of Energy \& Renewable Energy.

[34] National Solar Radiation Data Base, 2008, Available: http://rredc.nrel.gov/ solar/old_data/nsrdb/1991-2005/tmy3/(Online).

[35] W.J.K.B.L. Capehart, C.T. Wayne, Guide to Energy Management, 7th ed., Fairmont Press, 2011.

[36] B.L. Capehart, W.C. Turner, W.J. Kennedy, Economic analysis and life cycle costing, in: Guide to Energy Management, 7th ed., The Fairmont Press, 2013, pp. $131-172$

[37] R.G. Beaves, The case for a generalized net present value formula, Eng. Econ. (October) (2007).

[38] P.F. Ostwald, Review of 'Basic Cost Engineering' by Kenneth K. Humphreys and Sidney Katell, Marcel Dekker, Inc., New York, 1981, viii+2X8 Pages, List $\$ 29.50,2007$.

[39] ASHRAE Handbook - HVAC Systems and Equipment, ASHRAE, 2012

[40] A.A. Knizley, P.J. Mago, A.D. Smith, Evaluation of the performance of combined cooling, heating, and power systems with dual power generation units, Energy Policy 66 (March) (2014) 654-665.

[41] "Distributed Energy Resources: A How-To Guide," U.S. Department of Energy, National Renewable Energy Laboratory.

[42] I. Staffell, R. Green, K. Kendall, Cost targets for domestic fuel cell CHP, J. Power Sources 181 (July (2)) (2008) 339-349.

[43] Capstone Turbine, 2015, Available: http://www.capstoneturbine.com/ (Online).

[44] WSE Cogeneration, 2015, Available: http://www.cogeneration-energy.com/ (Online).

[45] Home | ComEd - An Exelon Company, 2015, Available: https://www.comed. com/Pages/default.aspx (Online).

[46] People's Natural Gas Price Comparison, 2015, Available: http://www.peoplesgas.com/PriceComparisons.aspx (Online).

[47] U.S. Environmental Protection Agency, Emission Factors for Greenhouse Gas Inventories, 2014, Available: http://www.epa.gov/climateleadership/ documents/emission-factors.pdf (Online).

[48] American Gas Association, "Full-Fuel-Cycle Energy and Emission Factors for Building Energy Consumption." Available: https://www.aga.org/sites/default files/21504_final_report_rev4_2014-01-30.pdf(Online). 